\title{
After Hurricanes Irma and Matthew: Living Shorelines Stabilize Sediments
}

\author{
Taryn Chaya*, Jessica Veenstra, \& Melissa Southwell \\ Flagler College Department of Natural Sciences, St. Augustine, Florida \\ bttps:/ / doi.org/10.33697/ ajur.2019.024 \\ Student:tarynchaya@outlook.com* \\ Mentor:jueenstra@flagler.edu
}

\begin{abstract}
Constructed intertidal oyster reefs, an example of a "living shoreline", can protect against erosion and loss of habitat, but can they prevent erosion during high-energy storm events such as hurricanes? Oyster reefs were constructed in 2012 within the Guana Tolomato Matanzas National Estuarine Research Reserve in Northeast Florida to stabilize the shoreline sediment and prevent erosion of an archeological site. Sediment cores were collected behind constructed oyster reefs before and after hurricanes Matthew (2016) and Irma (2017) to study changes in sediment particle size due to these high-energy storms. Pre-hurricane data were collected in 2016 from three different constructed reefs, as well as three control sites where no reef was present. Prehurricane sediment profiles behind the constructed reefs consisted of finer sediments, $\sim 36 \%$ silt and clay, in the surface $\sim 10-12$ $\mathrm{cm}$, with decreasing silt and clay and increasing sand content as depth increased. This was different than the sediment from the control sites with $\sim 4 \%$ silt and clay in all depths sampled. Like the sediment profiles before the high energy storms, the posthurricane sediment data showed a clear layer of finer sediment $\sim 10-12 \mathrm{~cm}$ over coarser sediment. Although they were high-energy storms, the storms did not appear to significantly affect the sediment behind the constructed oyster reefs. Sediment profiles remained consistent after these storms but may not remain undisturbed during the next storm without some intervention because the oyster reefs have been degrading.
\end{abstract}

\section{KEYWORDS}

Oyster Restoration; Living Shorelines; Hurricanes; Coastal Erosion; Sedimentation; Salt Marsh

\section{INTRODUCTION}

Salt marshes are low-energy coastal wetland ecosystems that provide several ecosystem services, such as erosion control, water filtration, and nutrient cycling. ${ }^{12,33}$ Salt marshes are naturally inhabited by organisms, such as cordgrasses (Spartina alterniflora) and eastern oysters (Crassostrea virginica), that trap sediment, prevent its resuspension from waves, and encourage sediment accretion. ${ }^{15,32}$ In recent years, these habitats have been threatened due to the impacts of human development and climate change-sea-level rise, intense storms, and human construction can be detrimental to wetlands. A natural solution becoming more widely accepted — the construction of living shorelines — is effectively stabilizing sediment. ${ }^{15,39}$ Living shorelines built along wetland shores, such as the construction of oyster reefs, replenishment of shoreline vegetation, or the use of other living materials, are designed to stabilize the shoreline from storms and boat wakes by providing a natural barrier, or breakwater. ${ }^{3,23,39}$ Oysters promote biodiversity, healthier water quality, and shoreline stabilization ${ }^{6,11}$; however, $85 \%$ of oyster reef ecosystems have been lost globally due to overharvesting, disease, and habitat destruction.2,18

Other methods of preventing coastal erosion are particularly popular in areas of coastal development. Commonly used to prevent erosion, built infrastructure such as sea walls, levees, and other hardening techniques can be difficult to maintain and can potentially lead to worsening shoreline conditions. ${ }^{1,38}$ Declining water quality and species diversity can result from the construction of these unnatural shoreline hardening techniques. ${ }^{1,13}$ Furthermore, shoreline hardening can increase erosion rates as waves and storm surge scour the structures and promote sediment resuspension. ${ }^{13}$ Despite mounting evidence showing the ineffectiveness of armored shorelines, ${ }^{1,8,13} 14 \%$ of the continental U.S.' tidal coastlines are unnaturally hardened. ${ }^{13}$ By using native plants and animals, living shorelines have been found to effectively attenuate waves, ${ }^{15,23}$ encourage local biodiversity, ${ }^{39}$ and recycle nutrients ${ }^{14}$ more efficiently than other hard armoring techniques such as bulkheads. Living shorelines can mitigate the effects of storms without damaging the ecosystem in the long run.

Shorelines respond geomorphologically to several factors - a combination of storms, human development, and sediment supply can significantly change the shape and profile of a shoreline. ${ }^{7,8,16,28}$ The combination of these conditions can influence whether a shoreline erodes or accretes sediment over time. ${ }^{19}$ Tropical storms and hurricanes can produce strong winds, storm surges, and 
large quantities of rain that tend to erode sediment. ${ }^{33}$ Extreme waves coupled with fluctuating water-levels influence the magnitude of shoreline change. ${ }^{34}$ Sediment is often naturally taken from shorelines during storm surge events and deposited elsewhere, known as allogenic sedimentation; 31,41 however, exposed shorelines with little barriers allow large amounts of sediment to be resuspended and eroded away in the event of a storm. ${ }^{26}$

For a shoreline to be stable, sediment accretion must occur at a rate that equals or exceeds the rates of sea-level rise and erosion. ${ }^{25}$ Salt marshes with low sediment accretion rates succumb to sea level rise, resulting in shoreward migration of plant and animal species. ${ }^{41}$ In response to rising sea level, however, oyster reefs can vertically and laterally accrete, as changes in inundation time and aerial exposure provide the conditions for continued growth. ${ }^{31}$ Furthermore, constructed oyster reefs can potentially outpace sea level rise at effectively higher rates than vegetation, such as cordgrasses and mangroves. ${ }^{31}$ Although vegetation can trap sediment and prevent erosion like oysters, high energy waves can uproot vegetation. ${ }^{12,21}$ Therefore, vegetation replenishment is a more effective living shoreline technique in areas of minimal boat wake and wave energy. On high energy coastlines, vegetative planting is more effective for buffering coastal erosion when it is in conjunction with other shoreline protection methods such as oyster reefs. ${ }^{42}$

The impacts of living shorelines in coastal habitats have been widely studied to gauge their usefulness in restoring ecosystem services. $1,14,38,39$ However, there has been limited research done regarding how living shorelines affect sediment distribution after storm events and their short and long-term effects after those storms.

In June 2012, the Guana Tolomato Matanzas National Estuarine Research Reserve (GTM Research Reserve) in Ponte Vedra Beach, Florida, USA constructed 28 eastern oyster reefs to protect an archeological site and prevent shoreline erosion. The creation of oyster reefs along the Tolomato River (the Intracoastal Waterway) was intended to attenuate wave energy from wind, storms, and boat wakes. Following their construction, previous studies estimated sediment accretion rates to be $5 \mathrm{~cm} / \mathrm{yr}$ directly behind the constructed reefs ${ }^{35}$ based on the thickness of the fine sediment layer (surface depths $\sim 0-10 \mathrm{~cm}$ in all reefs). One year after their restoration, the fine sediment reached a volume of $0.36 \mathrm{~m}^{3}$ behind the created reefs that were tested, compared to a fine sediment volume of $0.12 \mathrm{~m}^{3}$ at the control sites. ${ }^{35}$ The shift in particle size distribution in the surface depths indicated the created oyster reefs' ability to accumulate fine sediment and alter sediment profiles.

In October 2016 and September 2017, storms Matthew and Irma, a category two hurricane and tropical storm respectively when they reached the study site, 5,36 caused considerable damage to man-made structures in the community through storm surge and high winds. The GTM Research Reserve's System Wide Monitoring Program (SWMP) database showed turbidity and water levels increasing significantly during both storm events. Typically, turbidity values range from 4-20 NTU. During Matthew, turbidity was approximately 100 NTU and during Irma it was approximately 144 NTU. Water level typically ranges between approximately 2.5$4 \mathrm{~m}$. During Matthew, water level reached approximately $4.5 \mathrm{~m}$ and during Irma water level reached approximately $5.2 \mathrm{~m} .{ }^{27}$ The study site experiences frequent boat wakes and an average $1.6 \mathrm{~m}$ tidal range. ${ }^{17}$ The climate is temperate year-round, and the site's monthly average salinity ranges between $25-32$ ppt. $^{27}$

Our goal in this study was to investigate whether the constructed oyster reefs could effectively stabilize sediment following two major storms. If the oyster reefs were functioning as predicted, we would see (1) no change in the depth of fine sediment or (2) no deposition of coarse sediment at the surface or (3) no significant differences in the particle size distribution behind oyster reefs before and after the storms., 40

\section{METHODS AND PROCEDURES}

Recycled oyster shells were collected, put into plastic net bags, and placed in $5.3 \mathrm{~m}$ x $1.8 \mathrm{~m}$ x $0.5 \mathrm{~m}$ groups six meters apart along $315 \mathrm{~m}$ of the eastern shoreline of the Tolomato River. ${ }^{35}$

Sediment cores (22 cm depth; $7 \mathrm{~cm}$ diameter) were collected with a push corer before and after the storms to compare the sediment profiles and determine if the sediment had become disturbed due to these storms. Before the storms, in June 2016, one sediment core was taken from behind/landward each of three oyster reefs $(2,17,21)$ and at three control sites, where no reefs were present (Figure 1). Post-storms, in December 2017, sediment cores were collected from behind three different reefs (15, 16, 18). Getting to the site and taking the core mixes the sediment. We did not sample the same reefs twice in order to avoid artifacts due to disturbance from previous coring. 


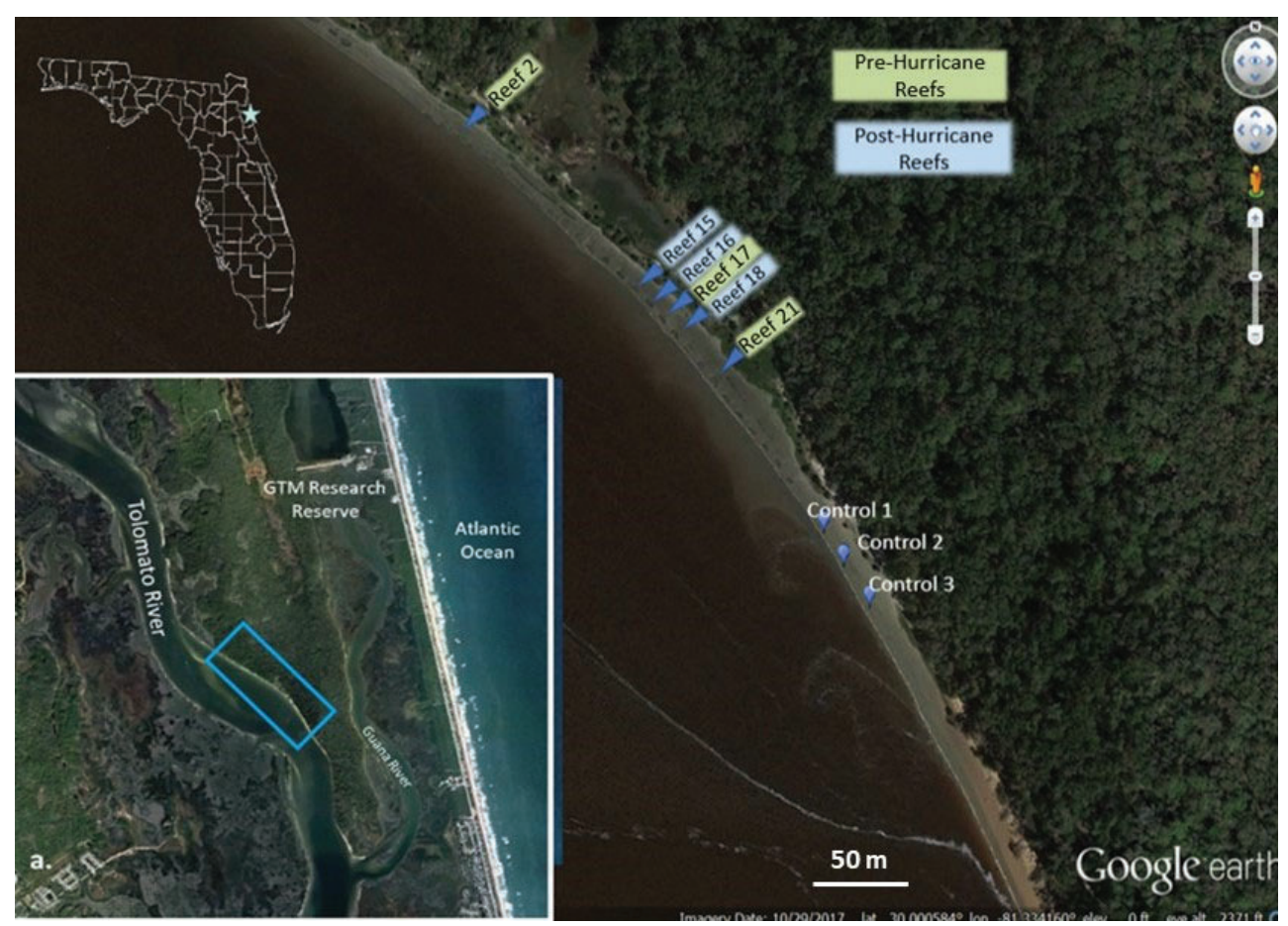

Figure 1. A map of the study site, along the Tolomato River in the GTM Research Reserve, showing the locations of the constructed oyster reefs. Sediment cores before the storms were taken from behind reefs 2, 17, and 21. Sediment cores taken after the storms were collected from behind reefs 15,16 , and 18. Pre-storms control samples were taken at the same elevation at three sites south of the constructed reefs along the same shoreline as the reef samples.

Sediment cores were sectioned into layers $2 \mathrm{~cm}$ thick, oven dried at $80^{\circ} \mathrm{C}$ for $1-3$ days and then sieved to allow sediment particles $>2 \mathrm{~mm}$ to be removed. Thirty grams of each sieved sediment sample was added to a pre-weighed 1-L Nalgene bottle. Drawing from a method created by Erftemeijer and Koch (2001) for studying sediment particle size in seagrass habitats, each sample was treated with increments of $15 \mathrm{~mL}$ of $30 \%$ concentrated hydrogen peroxide every two hours to remove organic matter for 48 hours to two weeks. ${ }^{10}$ Once visible chemical changes ceased (i.e. bubbling), organic matter was considered removed. Samples free of organic matter were placed into the oven overnight at $80^{\circ} \mathrm{C}$. The cooled, dry samples were weighed in grams to the nearest tenth-this value being the weight of the oven-dried sediment. One hundred milliliters of sodium hexametaphosphate, a dispersal chemical, was added to each sediment sample to separate the sediment particles before being shaken on an orbital shaker for two hours. The sediment samples were then wet sieved through a $63 \mu \mathrm{m}$ sieve to separate the sand (>63 $\mu \mathrm{m})$ from the silt $(63 \mu \mathrm{m}-4$ $\mu \mathrm{m})$ and clay $(<4 \mu \mathrm{m})$. The suspension of silt and clay particles sat undisturbed for at least an hour and a half in an $800 \mathrm{~mL}$ beaker (six hours maximum), while the $100 \mathrm{~mL}$ beaker of sand from the sediment sample could immediately be placed into the oven overnight. After the required hour and a half of complete rest, the clay suspended in the distilled water above the silt was poured off to allow the silt particles to be dried overnight. The following day, the oven-dried sand and silt samples were weighed. Following the simplified method for soil particle-size determination method synthesized by Kettler et al. (2001), the sand was then dry sieved in a sieve shaker composed of four layers: coarse $(2 \mathrm{~mm}-500 \mu \mathrm{m})$, medium $(500 \mu \mathrm{m}-250 \mu \mathrm{m})$, fine $(250 \mu \mathrm{m}-125$ $\mu \mathrm{m})$, and very fine $(125 \mu \mathrm{m}-63 \mu \mathrm{m})$ sands, for fifteen minutes. Each layer of sediment was weighed in grams, allowing us to determine the percentages of each particle size by dividing each particle size weight by the total oven-dried sediment mass from each sample. 9,20

Using the statistical software R, the Wilcoxon Ranked Sum Test determined if the percentages of the various particle size classes from cores collected before and after the storms were significantly different $(\alpha<0.05)$. This test was used because of our small sample size $(n=3)$. Although several sand particle size percentages were calculated (i.e. very fine sand, fine sand, medium sand, coarse sand), fine sand and silt and clay percentages were primarily used to convey our data because they composed the majority of the sample. Silt and clay percentages were added together to account for pouring and weighing errors that occurred in the procedure.

We determined the thickness of the fine sediment layer for each reef sampled. We defined the lower depth boundary of the fine sediment layer as (1) a silt and clay percentage decrease of at least 15\% or (2) an increase in fine sand percentage of at least $15 \%$. 


\section{RESULTS}

A fine sediment layer 10-12 $\mathrm{cm}$ deep was observed behind two out of the three reef sites in both the pre- and post-storm cores. When present, the fine layer consisted of $\sim 36 \%$ silt and clay in the surface $10-12 \mathrm{~cm}$, with a decrease in silt and clay $(\sim 18 \%)$ and increase in sand content in the deeper depths. The sediment cores from the control sites contained $\sim 4 \%$ silt and clay at most depths sampled (Figure 2). The pre-storm control samples are presented to emphasize the differences between sites with oyster reefs and those without - the implementation of the oyster reefs increased the amount of fine sediment (Figure 2).

We used the Wilcoxon Ranked Sum Test to test the null hypothesis that the pre-storm thickness of the fine sediment layer was equal to the post-storm thickness of fine sediment layer. The average fine sediment layer was not significantly different after the storms ( $p$-value $=0.45)$. However, our sample size is small $(n=3)$, and one reef from each pre-storm and post-storm sample did not exhibit the fine sediment layer at all (Reef 2 in the pre-storm samples and Reef 15 in the post-storm samples, Figures $\mathbf{3}$ and 4).

To determine if the storms deposited coarse sediment on the surface, we used the Wilcoxon Ranked Sum Test to test the null hypothesis that the pre-storm percent fine sand in the $0-4 \mathrm{~cm}$ depths was equal to the post-storm percent fine sand in the $0-4 \mathrm{~cm}$ depths. The average percentage of coarse sediment on the surface was not significantly different after the storms ( $\mathrm{p}$-value $=0.90)$. Although the differences were not statistically significant, there were lower percentages of silt and clay, and higher percentages of fine sand in the top $0-6 \mathrm{~cm}$ in two of the three post-storm reefs vs. the pre-storm reefs. Unfortunately, we had samples from the surface 0-2 and 2-4 cm where we did not have enough sample to process, so there were missing data points for reefs 16,18 , and 21.

To examine differences in the particle size distribution, we compared depth profiles of averaged percentages of fine sand and silt and clay between the pre-storm data, and post-storm data. P-values for Wilcoxon Ranked Sum Test are reported for each depth sampled. Post-storm percentages of fine sand and silt and clay was not significantly different from the pre-storm data (Figure 5).
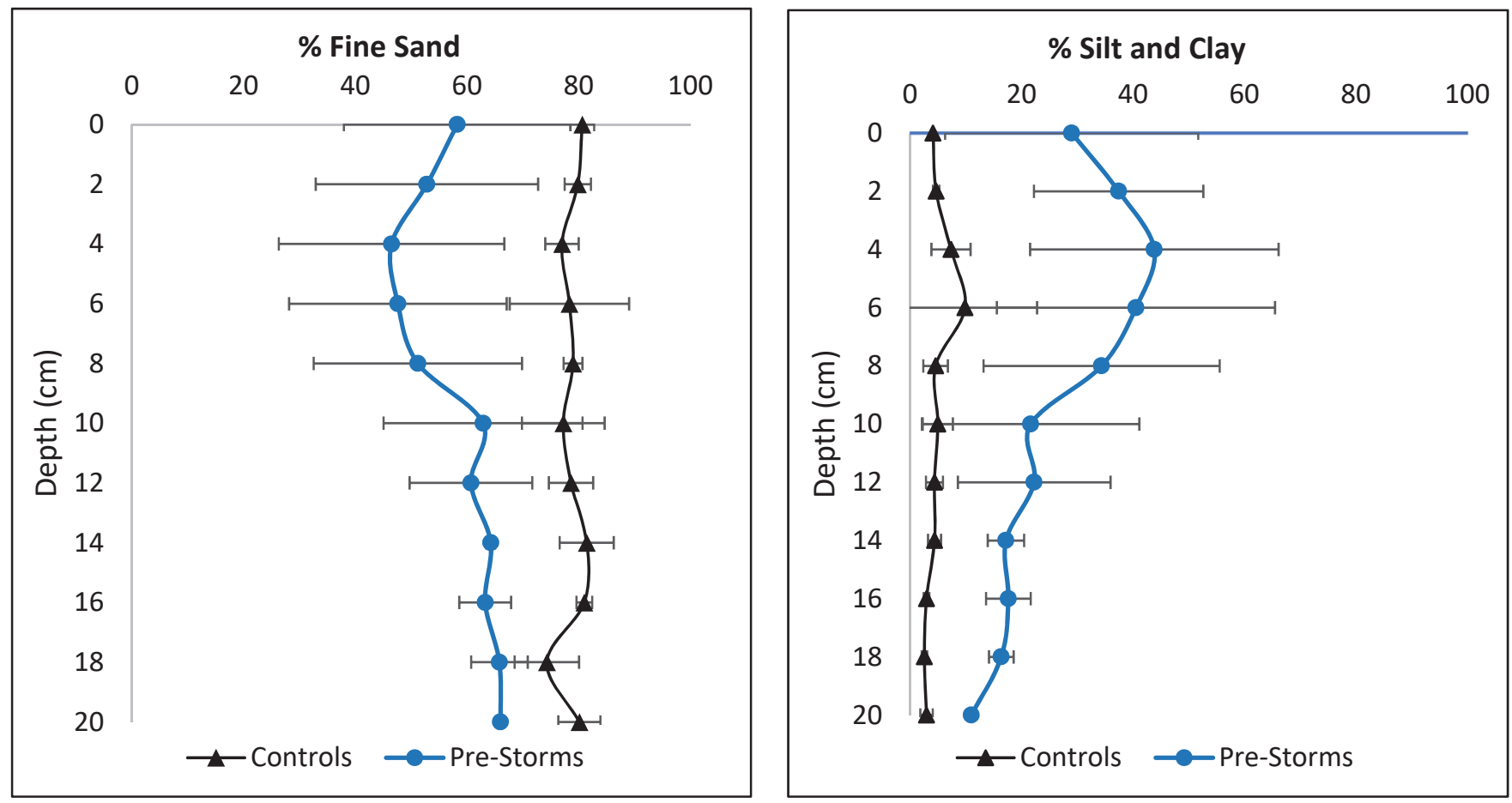

Figure 2. Percentages of fine sand (left), and silt and clay (right) plotted throughout the depths for control (black) and pre-storms (dark blue) data. The oyster reef construction increased the amount of finer sediment behind the reef. 


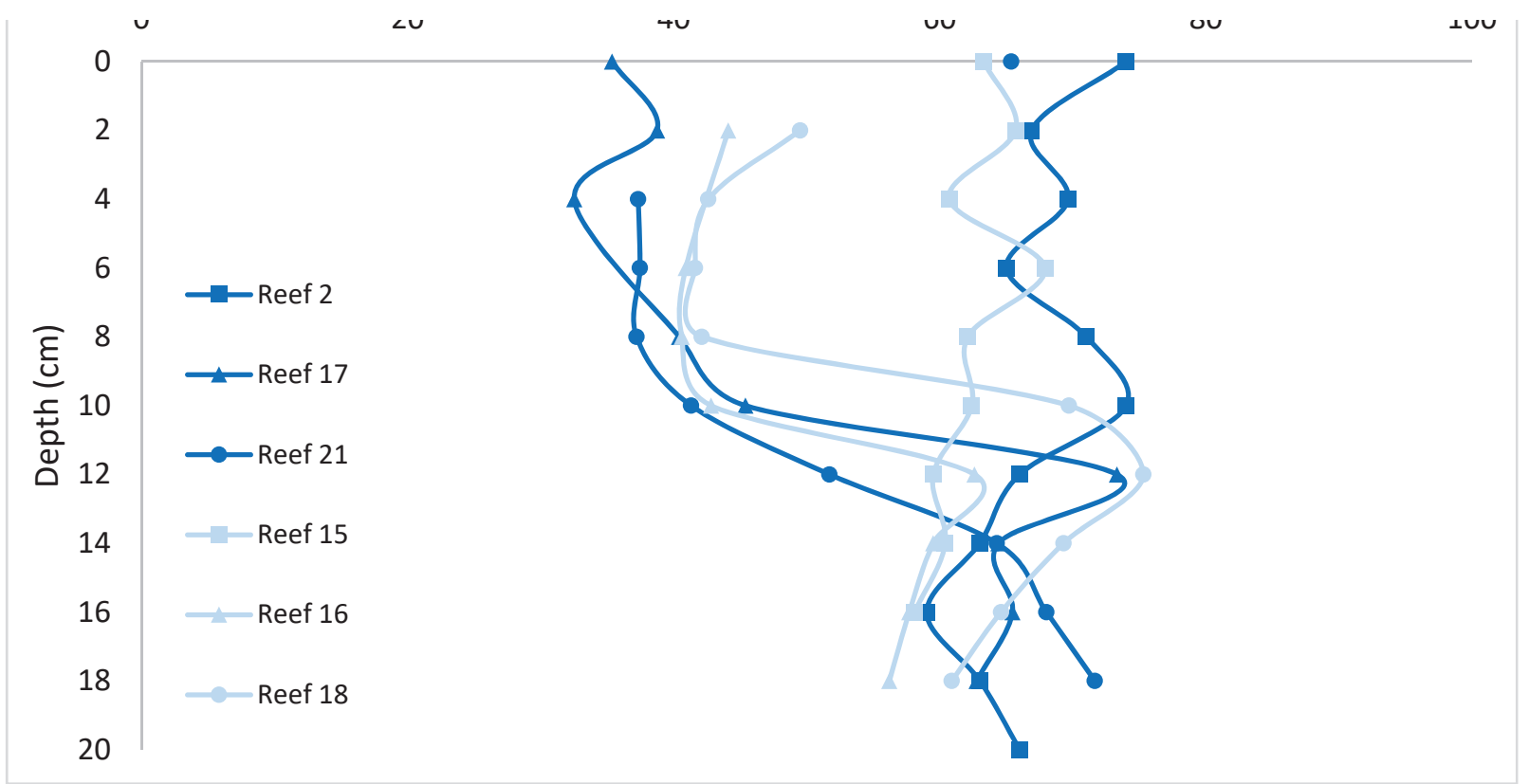

Figure 3. Individual percentages of fine sand for pre-storm (dark blue) and post-storm (light blue) sediment cores from depths of 0-20 cm.

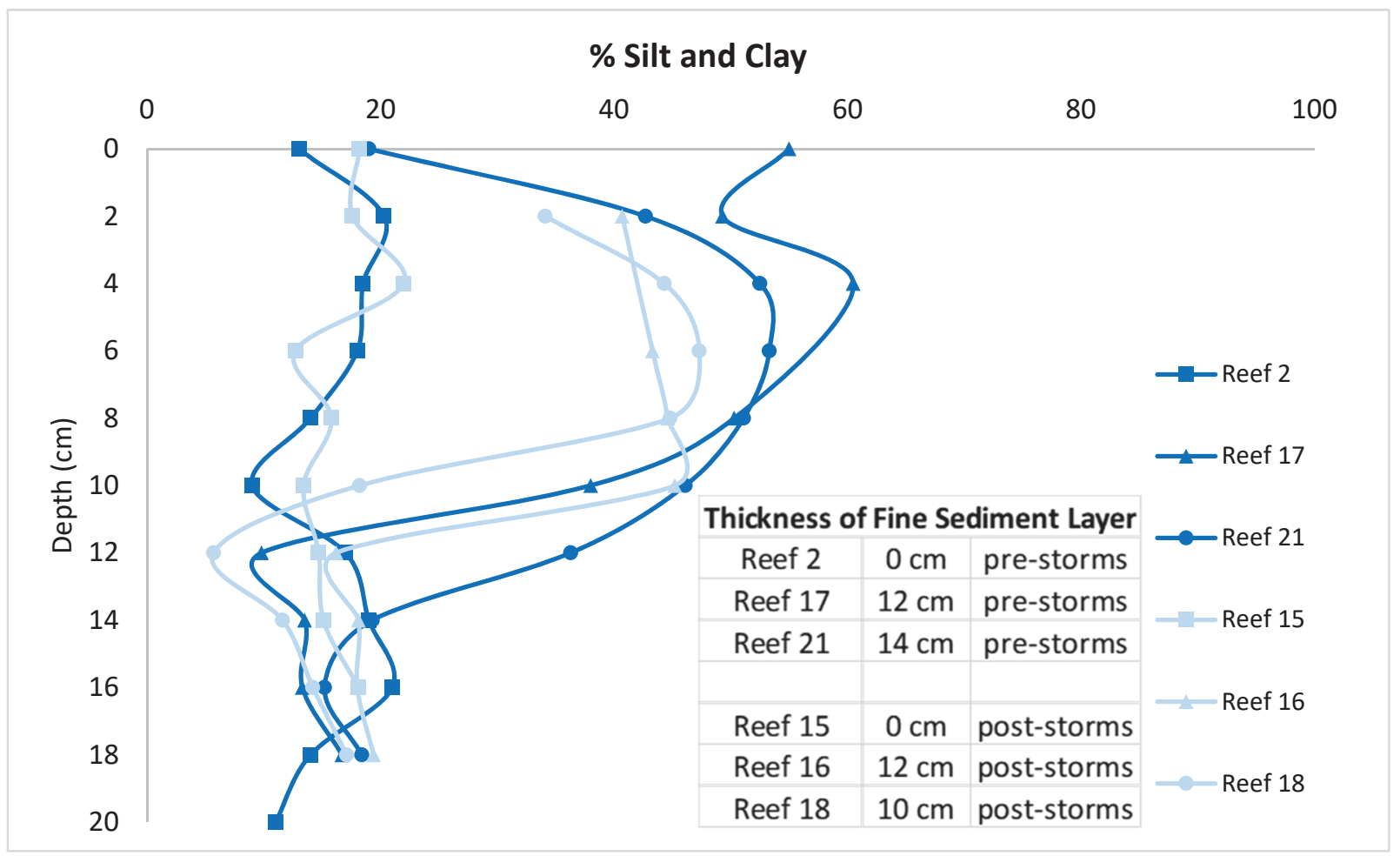

Figure 4. Percentages of silt and clay in pre-storm (dark blue) and post-storm (light blue) individual sediment cores. The table shows the depths where the profile shifted from fine sediment to coarser sediment. 


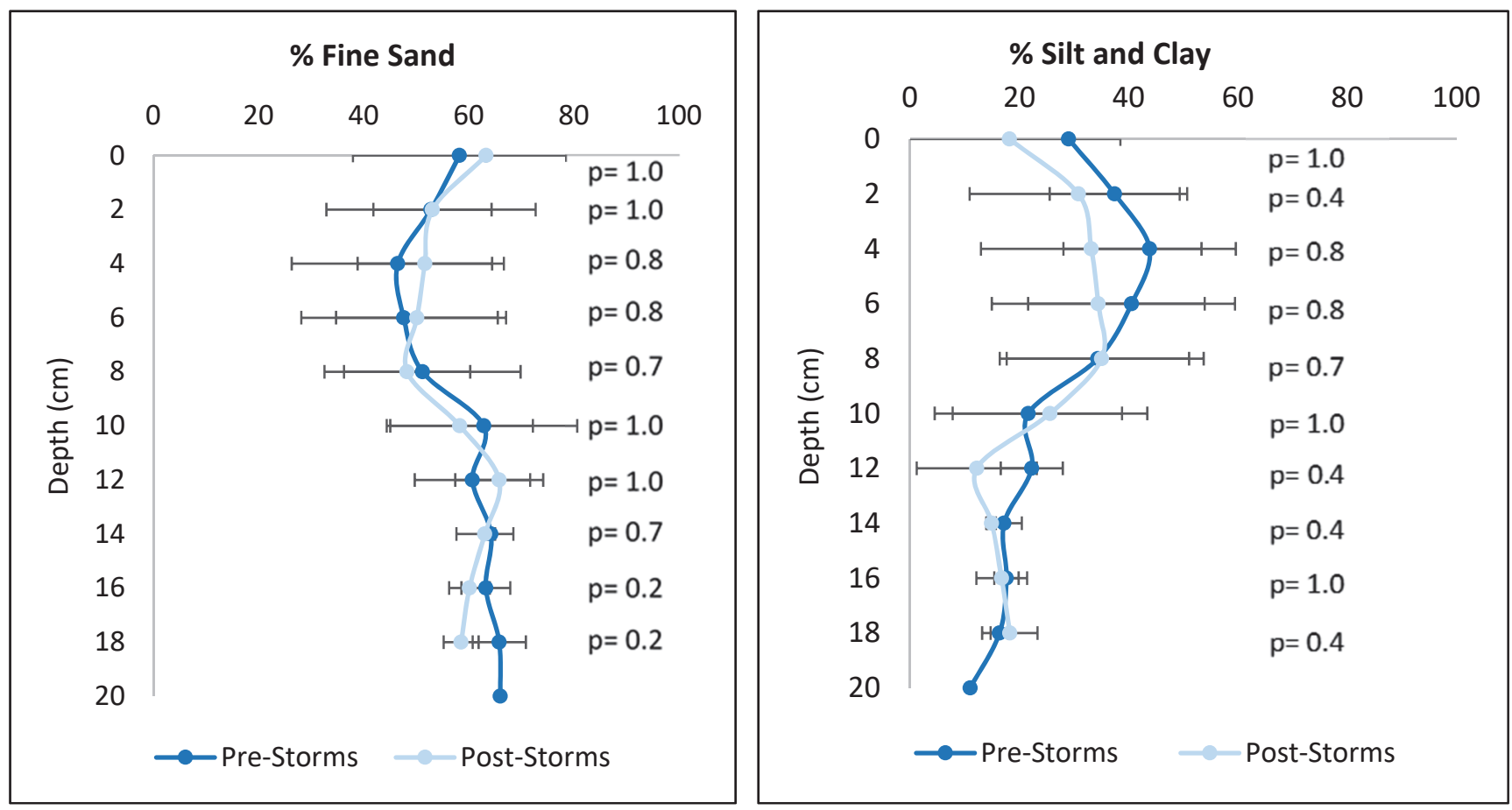

Figure 5. Average percentages of fine sand (left), and silt and clay (right) plotted throughout the depths for pre-hurricane and post-hurricane data with respective standard deviations. The overlapping standard deviations emphasize the similarities between the sediment profiles. Values on the right of each graph show the resulting $\mathrm{p}$-values $(\mathrm{n}=3)$ when comparing the pre- and post-hurricane data.

\section{DISCUSSION}

Our findings show no statistically significant differences in (1) the thickness of fine sediment layer, (2) the proportion of coarse sediment at the surface (percent fine sand in the $0-4 \mathrm{~cm}$ depth), or (3) the profile distribution of fine sand or silt and clay when comparing the pre- and post-storm reef cores. This could suggest that the oysters stabilized the shoreline sediment despite two strong storms.

Our small sample size, lack of post-storm control cores, and the potential to overestimate or underestimate the storms' impacts limit the strength of our conclusions. One core was collected from behind each of three reefs during each sample period (pre- and post-storms; pre-storm controls). One reef out of three showed variances; pre-storms' Reef 2 and post-storms' Reef 15 did not exhibit a surface fine sediment layer. Characteristic differences amongst the individual reefs, such as height and oyster density, may account for the variation in these sediment profiles.

Secondly, the strength of our conclusion is limited by the fact that we did not analyze post-storm control cores. After the storms, visual and texture-by-feel analysis ${ }^{40}$ indicated that the control sites continued to have a predominance of fine sand, and very little silt and clay, throughout the depth profile. Thus, even if we had analyzed sediment samples from the control sites, it would have been impossible to determine if erosion had removed sediment from the profile, if similarly textured, fine-sand sediments were deposited, or if the storms had not affected the sediments there at all.

Therefore, although we have evidence of the storms impacting the wider area through increased turbidity and high rainfall, the storm surge and higher water levels may mean that there was little impact on the sediment at the elevation of our oyster, and instead the storms may have had a bigger impact on the sediments at higher elevations. On the other hand, we could have underestimated impacts of the storms, given that we collected samples several months after the second storm, which could have given the sites time to reequlibrate. For example, sediment could have been eroded during one storm, and then been deposited during another.

Typically, storms decrease the thickness of fine sediment on the surface because of sediment resuspension and transport.,30 It does not appear that this occurred at our sites, because the thickness of the fine sediment layer was not significantly different in the pre-storm and post-storm cores. In low-energy environments, constructed oyster reefs have been found to be a viable option for preventing coastal erosion. ${ }^{22,29,39} \mathrm{~A}$ study in North Carolina, measuring sediment stabilization through accretion rate, determined sites with oyster shell had an average accretion rate of $+2.9 \mathrm{~cm}$ versus a loss of $-1.3 \mathrm{~cm}$ in sites without oyster shell. ${ }^{24}$ 
The oyster shell sites accreted a significantly larger amount of sediment compared to the areas without shell in each of their study sites. ${ }^{24}$ A significant storm event occurred during their same study—one site without oyster shell experienced heavy damage leading to a loss of $-3.2 \mathrm{~cm}$, versus an accretion rate of $+6.3 \mathrm{~cm}$ in the site with oyster shell during the storm. It was concluded that the oyster shell, coupled with vegetation, stabilized the sediment during the storm. ${ }^{24}$ Furthermore, differences in accretion rates between natural and constructed reefs have been investigated. In a study from the Grand Bay National Estuarine Research Reserve in Mississippi, all reefs prevented shoreline retreat, but constructed reefs were equally or more effective at doing so than natural reefs, due to increased oyster coverage. ${ }^{37}$

Sedimentation is a significant governing force of an oyster reef's health, as too much or too little sediment can bury or provide minimal substrate for further growth, respectively. ${ }^{31}$ Oysters themselves can alter the sediment surrounding them as they deposit organic matter and collect incoming sediment. ${ }^{42}$ Allogenic sediment, supplied by processes of sediment resuspension and erosion, contribute to oyster reef sediment accretion; however, coastal storms can alter the quantity of allogenic sediment available. ${ }^{25,36}$ Although we did not detect significant sediment changes behind the reefs, the oysters themselves were found to be partially buried in sediment before the storms. ${ }^{35}$ In addition to storm surge during hurricane season, oyster reef sites along the Tolomato River are also exposed to frequent boat wakes and wind-driven waves. After the storms, the reefs were considerably damaged, and their dead shell was spread over a large area of shoreline (Figure 6b). We cannot attribute the deterioration of the reefs to the storms however, because the plastic mesh bags holding the oysters together began breaking apart before the storms.

Constructed oyster reefs in North Carolina significantly decreased shoreline retreat in low-energy areas but were relatively ineffective at preventing erosion in high-energy environments, particularly after two storms. ${ }^{28}$ Shoreline retreat or lateral accretion was not measured in our study, but the stabilization of the sediment is evidence of prevented coastal erosion. The ineffectiveness in relatively high-energy environments found in other studies $28,29,39$ and the consequent damage of our constructed oyster reefs, suggests the need for more than one coastal erosion prevention method. ${ }^{23,38}$ Furthermore, effectiveness against storms and high wave energy is hindered if oysters cannot successfully accrete in pace with sea level rise, so shoreline protection from coastal erosion decreases as a result. ${ }^{24,31}$ Due to the current physical state of the oyster reefs following the two storms, it is unlikely that the reefs will keep pace with sea-level rise, especially in the high energy environment.

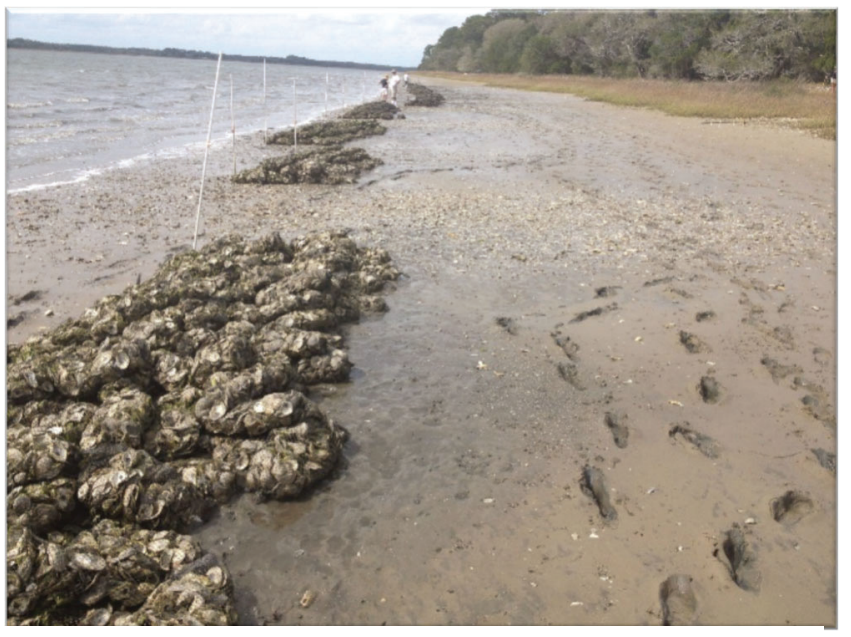

Figure 6a. The newly constructed oyster reefs at the study site in 2012 . The 28 reefs are made of net bags of recycled oyster shells.

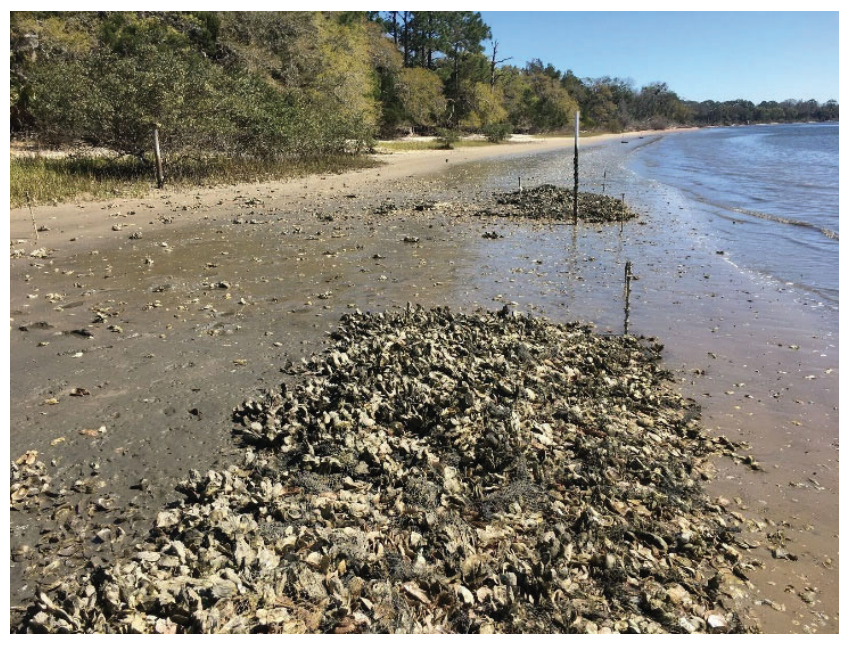

Figure $6 \mathrm{~b}$. The deteriorating state of the study site after Matthew and Irma.

\section{CONCLUSIONS}

The particle size distribution of sediment behind the constructed oyster reefs seems to have remained relatively consistent despite the occurrence of two strong storms. Fine sand and silt and clay percentages behind the oyster reefs were relatively similar before and after the storms, there was no statistically significant evidence of erosion of fine sediment or deposition of coarser sediment. Living shorelines can protect shorelines from erosion by attenuating high wave energy and trapping sediment. Unfortunately, significant damage has occurred on the oyster reefs at the GTM Research Reserve (Figure 6b). Although the reefs were able to attenuate the waves from the storms, intervention is needed to ensure they will protect the shoreline in the future. Further research could help identify if there are subsequent long-term effects to the sediment stabilization surrounding living shorelines at the GTM Research Reserve, such as stabilized carbon, increased elevation, and increased biodiversity. 


\section{ACKNOWLEDGEMENTS}

The authors thank Dr. Nikki Dix and the GTM Research Reserve, along with John Wooldridge the Flagler College Lab Manager, Colin Herbert, Chris Blanco, Dani Cayouette, Tim Mullen, Cody Burns, Aubrey Kemper, Courtney Cunningham, and the Flagler College Natural Sciences Department.

\section{REFERENCES}

1. Arkema, K. K. Guannel, G., Verutes, G., Wood, S. A., Guerry, A., Ruckelshaus, M., Kareiva, P., Lacayo M., and Silver, J. M. (2015) Coastal habitats shield people a property from sea-level rise, Nature Climate Change. doi:10.1038/nclimate1944

2. Beck, M. W., Brumbaugh, R. D., Airoldi, L., Carranza, A., Coen, L. D., Crawford, C., Defeo, O., Edgar, G. J., Hancock, B., Kay, M. C., Lenihan, H. S., Luckenbach, M. W., Toropova, C. L., Zhang, G., and Guo, X. (2011) Oyster Reefs at Risk and Recommendations for Conservation, Restoration, and Management, Bioscience 61(2), 107-116. doi:10.1525/bio.2011.61.2.5P.

3. Bradley, M., Morris, J. T. (1990) Physical characteristics of salt marsh sediments: ecological implications, Mar. Ecol. Pro. Ser 61, 245-252. doi: 0.3354/meps061245

4. Cahoon, D., Reed D. J., Day W. J., Steyer, G. D. Bouman, R., Lynch, J., McNally, D., Latif, N. (1995) The influence of Hurricane Andrew on Sediment Distribution in Louisiana Coastal Marshes, Journal of Coastal Research Special Issue (21), 280294.

5. Cangialosi, J.P., Latto, A.S., and Berg, R. (2018) National Hurricane Center Tropical Cyclone Report: Hurricane Irma. National Oceanic and Atmospheric Administration, Retrieved from bttps://www.nbc.noaa.gov/data/tcr/AL112017_Irma.pdf (accessed Sep 2018)

6. Coen L.D., Brumbaugh R.D., Bushek D., Grizzle R., Luckenbach M.W., Posey M.H., Powers S.P., Tolley S.G. (2007) Ecosystem services related to oyster restoration, Marine Ecology Progress 41, 303-307. doi:10.3354/ meps341303

7. Cowart, L., Walsh, J.P., and Corbett, D.R. (2010) Analyzing estuarine shoreline change: a case study of Cedar Island, North Carolina, Journal of Coastal Research 26(5), 817-830. https:/ / doi.org/10.2112/JCOASTRES-D-09-00117.1

8. Currin, C., Davis, J., Baron, C.L., Malhotra, A., Fonseca, M. (2015) Shoreline Change in the New River Estuary, North Carolina: Rates and Consequences, Journal of Coastal Research 31(5), 1069-1077. https:/ / doi.org/ 10.2112/JCOASTRES-D-1400127.1

9. Dalsgaard, Jensen, and Sorensen (2007) Small sample sieving and calibration. In Principles, Methods, and Application of Particle Size Analysis. Cambridge University Press. doi: 10.1017/CBO9780511626142

10. Erftemeijer, P.L.A. and Koch, E.W. (2001) Chapter 18 Sediment geology methods for seagrass habitat. In Global seagrass research methods. Ed. F.T. Short an R. G. Coles. Elsevier. doi: 10.1016/B978-044450891-1/50019-0

11. Garvis, S. K., Sacks, P. E., and Walters L. J. (2015) Formation, Movement, and Restoration of Dead Intertidal Oyster Reefs in Canaveral National Seashore and Mosquito Lagoon, Florida, Journal of Shellfish Research 34(2), 251-258.

https://doi.org/10.2983/035.034.0206

12. Gedan, K. B., Kirwan, M. L., Wolanski, E., Barbier, E. B., Silliman, B. R. (2010) The present and future role of coastal wetland vegetation in protecting shorelines: answering recent challenges to the paradigm, Climatic Change 106, 7-29. bttps:/ / doi.org/ 10.1007/s10584-010-0003-7

13. Gittman, R. K., Fodrie, J. F., Popowich, A. M., Keller, D. A., Bruno, J. F., Currin, C. A., Peterson, C. H. and Piehler, M. F. (2015) Engineering away our natural defenses: an analysis of shoreline hardening in the US, Frontiers in Ecology and the Environment 13(6), 301-307. bttps:// doi.org/10.1890/150065

14. Gittman, R. K., Peterson, C. H., Currin, C. A., Fodrie, J. F., Piehler, M. F., and Bruno, J. F. (2016) Living shorelines can enhance the nursery role of threatened estuarine habitats, Ecological Applications 26(1), 249-263. doi: 10.1890/14-0716.1

15. Grabowski, J. H. and Peterson, C. H. (2007) Restoring Oyster Reefs to Recover Ecosystem Services, Theoretical Ecology Series 4, 281-298. doi: 10.1016/S1875-306X(07)80017-7

16. Grizzle, Raymond E., Jamie R. Adams, and Linda Walters. (2002) Historical changes in intertidal oyster (Crassostrea virginica) reefs in a Florida lagoon potentially related to boating activities, Journal of Shellfish Research 21(2), $749-756$.

17. Herbert, D., Astrom, E., Bersoza, A. C., Batzer, A., McGovern, P., Angelini, C., Dix, N., and Sheremet, A. (2018) Mitigating Erosional Effects Induced by Boat Wakes with Living Shorelines, Sustainability 10(2), 436. https://doi.org/10.3390/su10020436

18. Jackson, Jeremy B. C. Kirby, M. X., Berger, W. H., Bjorndal, K. A., Botsford, L. W., Bourque, B. J., Bradbury, R. H., Cooke, R., Erlandson, J., Estes, J. A., Hughes, T. P., Kidwell, S., Lange, C. B., Lenihan, H S., Pandolfi, J. M., Peterson, C. H., Steneck, R. S., Tegner, M. J., Warner, R. R. (2001) Historical Overfishing and the Recent Collapse of Coastal Ecosystems, Science 293(5530), 629-637. doi: 10.1126/science.1059199

19. Kish, Stephen K. and Joseph F. Donoghue (2013) Coastal Response to Storms and Sea-Level Rise: Santa Rosa Island, Northwest Florida, U.S.A., Journal of Coastal Research 63, 131-140. https:/ / doi.org/10.2112/SI63-012.1

20. Kettler, T.A, Doran, J.W., and Gilbert, T.L. (2001) Simplified Method for Soil Particle-Size Determination to Accompany Soil-Quality Analyses. Soil Science Society of America Journal 65, 849-852. doi: 10.2136/sssaj2001.653849x 
21. Knutson, P. L., Ford, J. C., Inskeep, M. R., and Oyler, J. (1981) National survey of planted saltmarshes (vegetative stabilization and wave stress), Wetlands 1, 129-157. doi: 10.1007/BF03160460

22. La Peyre, M. K., Serra, K., Joyner, T. A. and Humphries, A. (2015) Assessing shoreline exposure and oyster habitat suitability maximizes potential success for sustainable shoreline protection using restored oyster reefs, PeerJ 3:e, 13-17. doi:10.7717/peerj.1317

23. Manis, J. E., Garvis, S. K., Jachec, S. M., and Walters, L. J (2015) Wave attenuation experiments over living shorelines over time: a wave tank study to assess recreational boating pressures, Journal of Coastal Conservation 19, 1-11. doi: 10.1007/s11852014-0349-5

24. Meyer, D.L., Townsend E.C., Thayer G.W. (1997) Stabilization and erosion control value of oyster cultch for intertidal marsh, Restoration Ecology 5, 93-99. doi: 10.1046/j.1526-100X.1997.09710.x

25. Morris, J. T., Sundareshwar, P. V., Nietch, C. T., Kjerve, B., and Cahoon, D.R. (2002) Responses of Coastal Wetlands to Rising Sea Level, Ecology 83(10), 2869-2877. doi: 10.1890/0012-9658(2002)083 [2869:ROCWTR]2.0.CO;2

26. Morton, R. A. and Barras, J. A. (2011) Hurricane Impacts on Coastal Wetlands: A Half-Century Record of Storm-Generated Features from Southern Louisiana, Journal of Coastal Research 27(6A), 27-43. doi: 10.2307/41315913

27. NOAA National Estuarine Research Reserve System (NERRS). System-wide Monitoring Program. Data accessed from the NOAA NERRS Centralized Data Management Office website: http://www.nerrsdata.org/; accessed 31 July 2019.

28. Phillips, J. D. (1999) Event Timing and Sequence in Coastal Shoreline Erosion: Hurricanes Bertha and Fran and the Neuse Estuary, Journal of Coastal Research 15(3), 616-623.

29. Piazza, B. P., Banks, P. D., La Peyre, M. K. (2005) The Potential for Created Oyster Shell Reefs as a Sustainable Shoreline Protection Strategy in Louisiana, Restoration Ecology 13(3), 499-506. https:/ / doi.org/ 10.1111/j.1526-100X.2005.00062.x

30. Reese, C. A., Strange, T. P., Lynch, W. D., Liu K. (2008) Geologic Evidence of Hurricane Katrina Recovered from the Pearl River Marsh, MS/LA, Journal of Coastal Research Vol. 24(6), 1601-1607. bttps:/ / doi.org/10.2112/07-0956.1

31. Rodriguez, A. B., Fodrie, J., Ridge, J., Lindquist, N. L., Theuerkauf, E. J., Coleman S. E., Grabowski, J. H., Brodeur M. C., Gittman, R. K., Keller, D. A., and Kenworthy, M. D. (2014) Oyster reefs can outpace sea-level rise, Nature Climate Change 4, 493-497. doi: 10.1038/NCLIMATE2216

32. Schuerch, M., Dolch, T., Bisgwa, J. and Athanasios T. Vafeidis (2018) Changing Sediment Dynamics of a Mature Backbarrier Salt Marsh in Response to Sea-Level Rise and Storm Events, Frontiers in Marine Science 5(155), 1-14. doi: 10.3389/fmars.2018.00155

33. Scott, D. B., Frail-Gauthier, J., and Mudie, P. J. Coastal Wetlands of the World. New York: Cambridge University Press, 2014. Print.

34. Scyphers S. B., Powers S. P., Heck K. L. Jr, Byron D. (2011) Oyster Reefs as Natural Breakwaters Mitigate Shoreline Loss and Facilitate Fisheries. PLoS ONE 6(8): e22396. doi: 10.1371/journal.pone.0022396

35. Southwell, M. W., Veenstra, J. J., Adams, C. D., Scarlett, E. V. and Payne, K. B. (2017) Changes in Sediment Characteristics upon Oyster Reef Restoration, NE Florida, USA, Journal of Coastal Zone Management 20(1), 1-7. doi: 10.4172/24733350.1000442

36. Stewart, S. R. (2016) National Hurricane Center Tropical Cyclone Report: Hurricane Matthew. National Oceanic and Atmospheric Administration, Retrieved from https:/ / www.nhc.noaa.gov/data/tcr/AL142016_Matthew.pdf. (accessed Sep 2018)

37. Stricklin, A. G., M. S. Peterson, J. D. Lopez, C. A. May, C. F. Mohrman and Woodrey, M. S. (2010) Do Small, Patchy, Constructed Intertidal Oyster Reefs Reduce Salt Marsh Erosion As Well As Natural Reefs?, Gulf and Caribbean Research 22(1), 21-27. doi: $10.18785 /$ gcr.2201.03

38. Sutton-Grier, A. E., Wowk, K., and Bamford, H. (2015) Future of our coasts: The potential for natural and hybrid infrastructures to enhance the resilience of our coastal communities, economies, and ecosystems, Environmental Science and Policy 51(1), 137-148. https:// doi.org/10.1016/j.envsci.2015.04.006

39. Swann, L. (2008) The Use of Living Shorelines to Mitigate the Effects of Storm Events on Dauphin Island, Alabama, U.S.A., American Fisheries Society 64(1), 1-12.

40. Vos, C., Don, A., Prietz, R., Heidkamp, A., Freibauer, A. (2016) Field-Based Soil Texture Estimates Could Replace Laboratory Analysis. Geoderma 267, 215-219.

41. Warren, S. R. and Niering, W. A. (1993) Vegetation Change on a Northeast Tidal Marsh: Interaction of Sea-Level Rise and Marsh Accretion, Ecology 74(1), 96-103. doi: 10.2307/1939504

42. Ysebaert T., Walles B., Haner J., Hancock B. (2019) Habitat Modification and Coastal Protection by Ecosystem-Engineering Reef-Building Bivalves. In: Smaal A., Ferreira J., Grant J., Petersen J., Strand Ø. (eds) Goods and Services of Marine Bivalves. Springer, Cham. https:// doi.org/10.1007/978-3-319-96776-9_13

\section{ABOUT STUDENT AUTHOR}

Taryn Chaya graduated from Flagler College in May 2019 with a degree in Coastal Environmental Science. Taryn is pursuing a master's degree in Soil and Water Science at the University of Florida. She hopes to use this degree to remediate or prevent the negative effects climate change and anthropogenic factors place on wetland ecosystems. 


\section{PRESS SUMMARY}

Shoreline loss due to storms, sea level rise, and human activities is becoming increasingly prevalent. Coastal erosion prevention practices are gaining traction as shoreline loss continues to threaten economic and natural systems in coastal cities-living shorelines have been considered a long-term solution to coastal erosion in comparison to hard structures like seawalls. In St. Augustine, FL, two major storms, hurricane Matthew and tropical storm Irma, caused significant infrastructural and natural damage. Living shorelines, such as the construction of oyster reefs or replenishment of vegetation can buffer waves and trap sediment during storms. Oyster reefs were constructed at the Guana Tolomato Matanzas National Estuarine Research Reserve (GTM Research Reserve) in Northeast Florida to stabilize the shoreline sediment and prevent the erosion of an archeological site. Sediment cores were collected behind constructed oyster reefs at the GTM Research Reserve before and after the two storms, and although they were high-energy storms, they did not significantly change the sediment behind the constructed oyster reefs. This suggests that the constructed oyster reefs adequately protected the sediment from erosion during the storm events. 